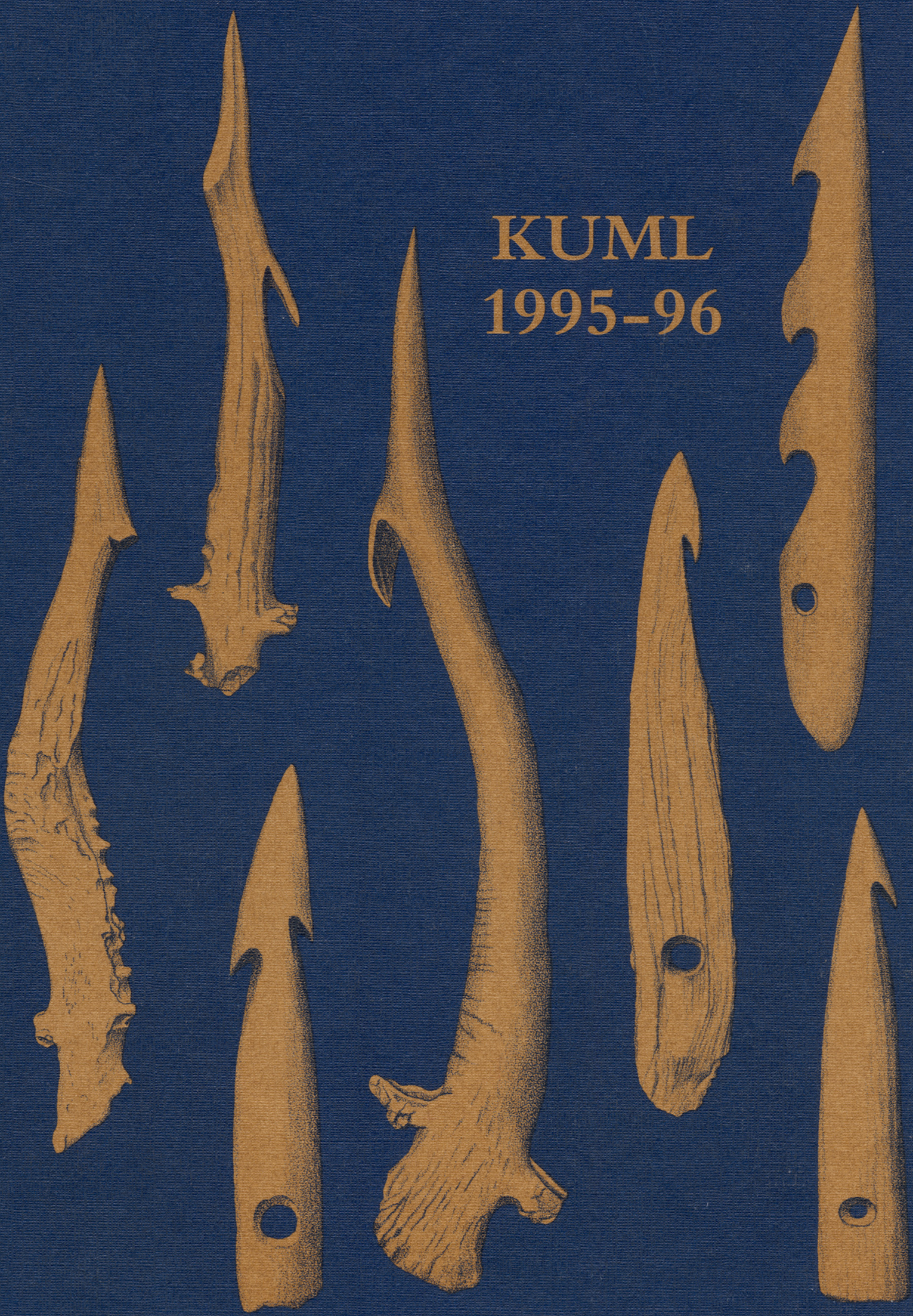


KUML 1995-96 


\section{KUML 1995-96 \\ Årbog for Jysk Arkæologisk Selskab}

With summaries in English

I kommission hos Aarhus Universitetsforlag, Århus 
Redaktion: Hans Jørgen Madsen og Jesper Laursen

Omslag: Jorgen Mührmann-Lund

Grafisk tilretteloggelse: Elsebet Morville

Tryk: Narayana Press

Skrift: Bembo 12/13

Papir: $115 \mathrm{~g}$ Arctic Silk

Copyright (C) 1997 by Jysk Arkcoologisk Selskab

ISBN 87-7288-592-0

ISSN 0454-6245 


\section{Indhold/Contents}

Palle Friis: Poul Kjærum. Worsaae-medaillen 16. maj 1996 ............................. 7

Poul Kjærum. Worsaae medal ........................................................ 10

Ole Høiris: Kampen om stenalderen. Antropologiske bud på vor oprindelse

i fortid og nutid ..................................................................................... 13

Fight over the Stone Age ................................................................. 44

Søren H. Andersen: Ertebølleharpuner og spækhuggertænder. Aspekter af marin fangst i Ertebølletid ............................................................. 45

Ertebølle harpoons and killer whale teeth. Aspects of marine hunting

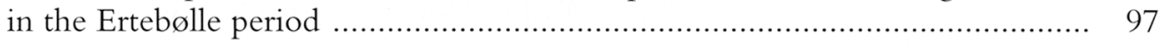

Klaus Ebbesen: Terningspil i yngre stenalder …........................................ 101

Dice and Dicing in the Stone Age ............................................... 111

Carsten Korthauer: En ældre romertidsgrav med guldmønt fra Jylland - samt nogle iagttagelser om møntomløb og -funktion i jernalderens Danmark ......... 113

An Early Roman Iron Age Grave containing a Roman Gold Coin ............. 133

Poul Mikkelsen og Lis Helles Olesen: Vendeldiget ........................................... 135

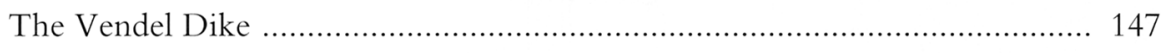

Jens Jeppesen og H.J. Madsen: Trækirke og stormandshal i Lisbjerg ...................... 149

A Wooden church and Big Man's Hall at Lisbjerg ..................................... 169

Mogens Rud: En skjult sandhed i Bayeux-tapetet? Hvad skulle Harald

Godwinson i Normandiet? ....................................................... 173

A hidden Revelation in the Bayeux tapestry? What was Harald

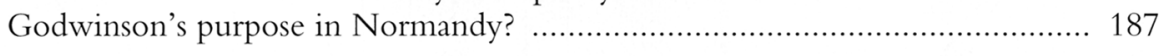

Hans Skov: Udgravningerne ved Aarhus Katedralskole i 1994-95 ....................... 189

Excavations at Aarhus Cathedral School in 1994-95 .................................. 206

Jette Linaa Larsen: Skår i tusindtal - keramik fra Torvet i Horsens

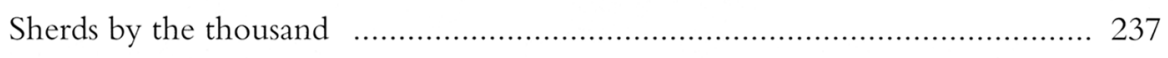

Jens Andersen: Jydepotter fra Brønderslev ................................................. 239

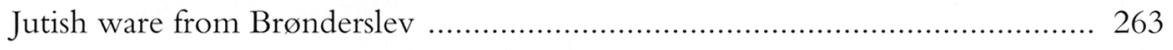

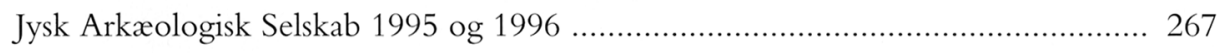




\title{
Udgravningerne ved Aarhus Katedralskole i 1994-95
}

\author{
Af Hans SKov
}

Som optakt til Aarhus Katedralskoles 800-års jubilæum i 1995, foretog Moesgård Museum på skolens opfordring nogle mindre arkæologiske undersøgelser $i$ et forsøg på at belyse skolekompleksets bebyggelseshistorie (1). Første undersøgelse fandt sted i 1994 og året efter gav udskiftningen af fjernvarmeledninger i henholdsvis Skolegyde og Skolegade anledning til nye arkæologiske undersøgelser af Katedralskolens gamle grund (2). Det er resultaterne af disse to arkæologiske undersøgelser, der her fremlægges. På fig. 1 er det område markeret, hvor de arkæologiske undersøgelser fandt sted.

Som navnet antyder, var Katedralskolen i sin oprindelse knyttet direkte til domkirken. I middelalderen var kirkesproget latin, og fra en pavelig rundskrivelse fra 1073 ved man, at alle bisper i Kristenheden ved deres hovedkirke skulle sørge for skoling af nye præster i latin (3). Dette indebar oprettelsen af katedralskoler ved alle domkirker, men hvor hurtigt disse skoler i realiteten blev oprettet, ved man meget lidt om. Der er imidlertid god grund til at tro, at allerede Århus's forste Skt. Nicolai domkirke (nu Vor Frue kirke) havde en form for katedralskole fra slutningen af 1000-årene, og at denne flyttede med hen til den nuværende placering ved grundlæggelsen af Skt. Clemens domkirken i 1190’erne (4).

\section{Udgravningen i Katedralskolens skolegård}

Ved udgravningen i 1994 blev to udgravningsfelter på i alt $32 \mathrm{~m}^{2}$ anlagt i skolegårdens sydlige halvdel. Deres placering ses på fig. 2. Når begge felter blev placeret i skolegårdens sydlige halvdel, skyldes det, at museet tidligere har gennemført en arkæologisk udgravning på skolegårdens nordlige halvdel. Denne er udførligt publiceret i Kuml 1985 og viste, at Katedralskolens middelalderlige forgænger ikke skulle søges her, men længere mod syd (5). Udgravningsfelterne i 1994, der benævnes Felt I og Felt II, blev lagt på steder, hvor der var begrundet håb om at træffe levn fra ældre huse tilhørende Katedralskolekomplekset, samt levn af den forudgående bebyggelse fra vikingetiden. Ved Felt I viste gamle kort og tegninger, at her havde den gamle rektorbolig stået indtil anden halvdel af 1800-årene. Siden havde en fløj af skolen stået på stedet indtil 1950'erne 


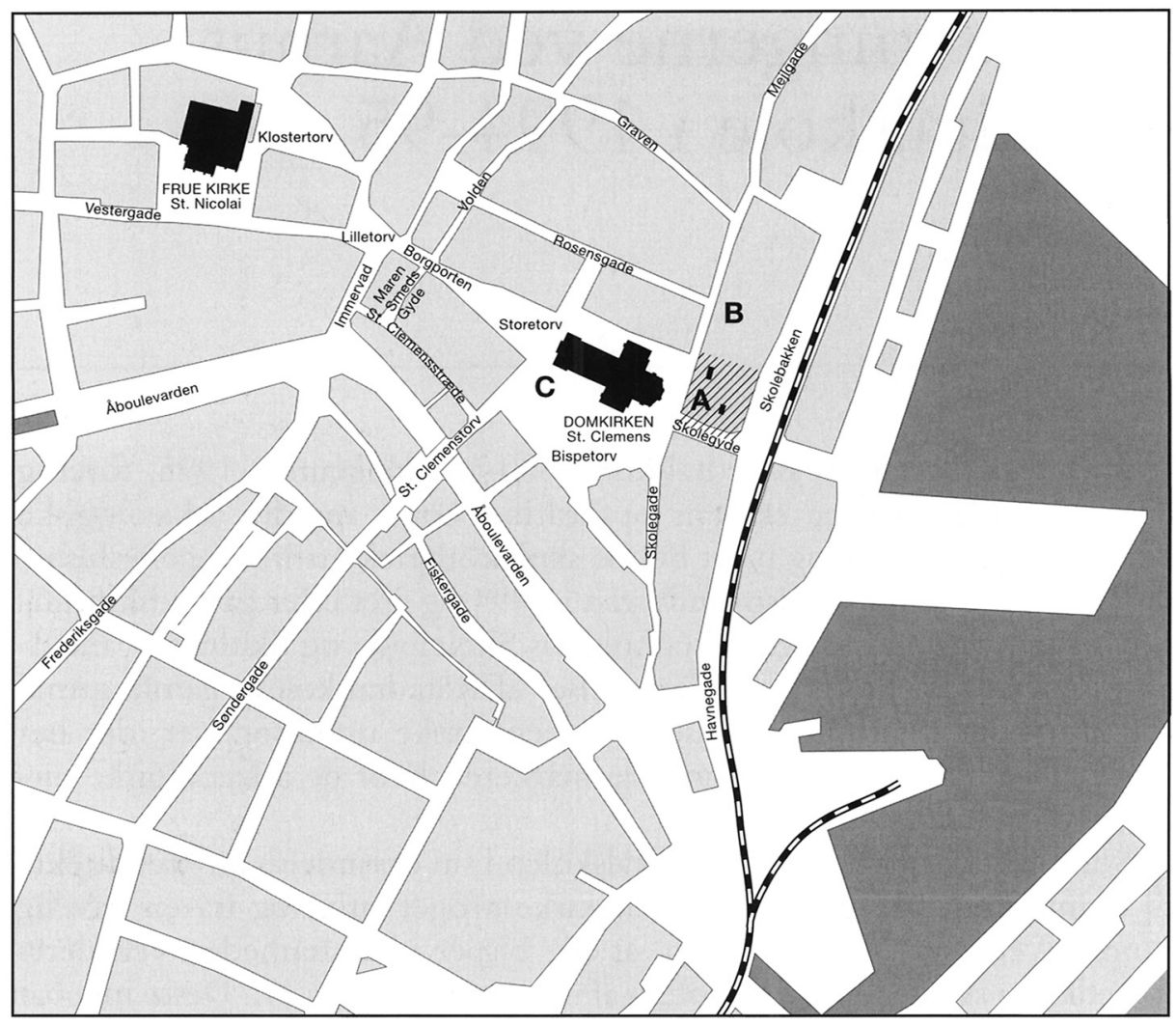

Fig. 1. Det indre Århus. Det markerede område A er Katedralskolens gamle grund, hvor de arkæologiske undersøgelser i 1994-95 fandt sted. B Området med udgravningen fra 1969. C er domkirken.

Central Århus. A is the old property of the Cathedral School where the excavations took place. $\mathrm{B}$ is the site of the excavation from 1969. C is the cathedral.

(6). Udgravningen skulle gerne kaste lys over alderen på den gamle rektorbolig af bindingsværk, der måtte vige $\mathrm{i}$ anden halvdel af 1800-tallet, samt om der var spor af endnu ældre bygninger på stedet. Ved Felt II var man ved ledningsarbejder tidligere stødt på en murrest, hvis alder var ukendt.

Til bortgravning af fliser og aflejringer fra nyere tid blev benyttet en rendegraver. I begge felter blev omtrent den øverste meter på denne måde bortgravet, hvorefter felterne blev undersøgt intensivt, dels ved manuelt at bortgrave jorden i $10 \mathrm{~cm}$ tykke vandrette lag og dels, hvor det var muligt, at grave stratigrafisk. Det var naturligvis kun muligt at udgrave lagene stratigrafisk, når det enkelte lag på klar vis lod sig udskille fra de øvrige. Alle påtrufne genstande blev indsamlet og indmålt enkeltvis eller henført til de lag, de blev fundet i. 


\section{Aflejringer og bebyggelse}

Skolegårdens flisebelægning lå ved Felt I ca. 4,81 meter over DNN (Dansk Normal Nul), mens Felt II, der var nærmere ved den gamle kystskrænt ved Skolebakken, havde en overfladekote omkring 4,66 m. over DNN. Fig. 3 viser Felt I under udgravning.

Felt $I$ viste sig at være placeret et sted med flere dybtgående kloakledninger, der kunne følges helt ned i den sterile undergrund. Uden for disse moderne forstyrrelser bestod de øverste $70 \mathrm{~cm}$ af nye og omrodede efterreformatoriske lag. På fig. 4 er disse lag m.m. angivet med priksignatur. Herunder lå der op til $90 \mathrm{~cm}$ tykke uforstyrrede kulturlag fra 1500-1600-årene (fig. 4 ). Under disse kulturlag er der middelalderlag fra ca. 1200-1250 med en samlet tykkelse på ca. $30 \mathrm{~cm}$. Under middelalderlagene var der knap 40 $\mathrm{cm}$ tykke kulturlag fra vikingetidens senere del. Det er værd at bemærke, at der er et tidsmæssigt spring mellem kulturlagene fra vikingetiden, middelalderen og 1500-1600-årene. Forklaringen på dette fænomen kan være bortgravninger af ældre kulturlag i forbindelse med afsætning af yngre lag. Man kan også forestille sig, at man har haft flader (brolægninger o.lign.), der er blevet renholdt i lange perioder, inden de er blevet opgivet, og nye lag har haft lejlighed til at aflejre sig. Det er et ganske normalt fænomen, at man optager stenene fra ældre nedlagte brolægninger og genbruger dem i et højere niveau. Sporene fra sådanne brolægninger kan således næsten helt forsvinde. I Felt I var lagene fra vikingetiden bevaret op til kote 3,32 m over DNN. Topkoten af undergrunden var lige omkring 3,00 m over DNN. Det betyder at der på dette sted er 1,81 m fra fliserne i skolegården til den sterile undergrund.

To fundamenter blev påtruffet i Felt I. Længst mod nord (jf. fig. 2) var der rester af den fløj, der blev nedrevet i 1950'erne. Parallelt hermed, men $80 \mathrm{~cm}$ sydligere, lå resterne af fundamentet fra den gamle rektorbolig, der blev nedrevet i anden halvdel af 1800-årene. Dette fundament - kaldet o kunne stratigrafisk henføres til nyere tid. Arkæologisk er det ikke muligt at sige, om denne bygning var opført i 1600-årene eller senere, men ud fra en tegning af bygningen at dømme ser den ud til at være opført af bindingsværk fra tidligt i 1700-årene (7). Den gamle rektorboligs fundament bestod af et lyst brunt lerlag med store flade kampesten som syldsten.

Ud over de to fundamenter var der ikke spor af andre konstruktioner i Felt I. I undergrundsniveau kunne flere stolpehuller og gruber iagttages, men der var ikke noget system i disse nedgravninger, i modsætning til hvad der var tilfældet ved den tidligere udgravning på skolegårdens nordlige halvdel, hvor tre grubehuse fra vikingetid blev påvist (8).

Fundene i Felt I bestod især af keramik og jerngenstande. I lagene fra vikingetiden sås skår fra halvkuglekar og lokalt produceret slavisk inspireret Østersøkeramik. Begge typer hører til den fra Århus Søndervold 


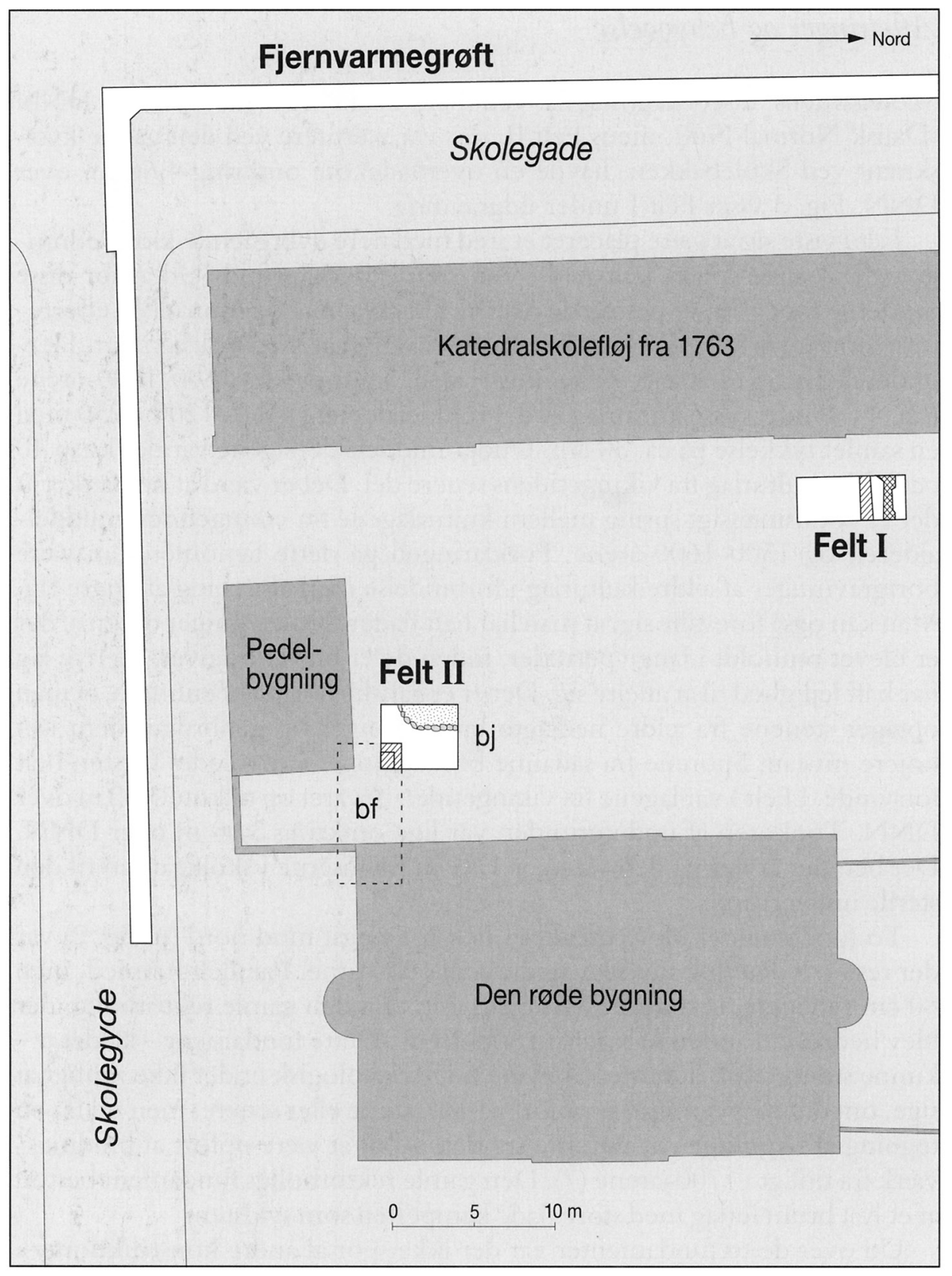

Fig. 2. De arkæologisk undersøgte områder i skolegården, Skolegyde og Skolegade. De påviste huslevn er vist, samt de nærmeste af Katedralskolens nuværende bygninger.

The excavated areas in the playground, and Skolegyde and Skolegade. Archaeological building remains and the nearest of the Cathedral School's present buildings are shown. 
Fig. 3. Felt I under udgravning. Det nærmeste fundament $\mathrm{i}$ baggrunden er fra den gamle rektorbolig. Det fjerneste fundament er moderne. Set fra syd.

Foto: H. Skov.

Square I during excavation. The nearer foundation at the rear is the old headmaster's house, the further are modern. Seen from $\mathrm{S}$.

Photo H. Skov.

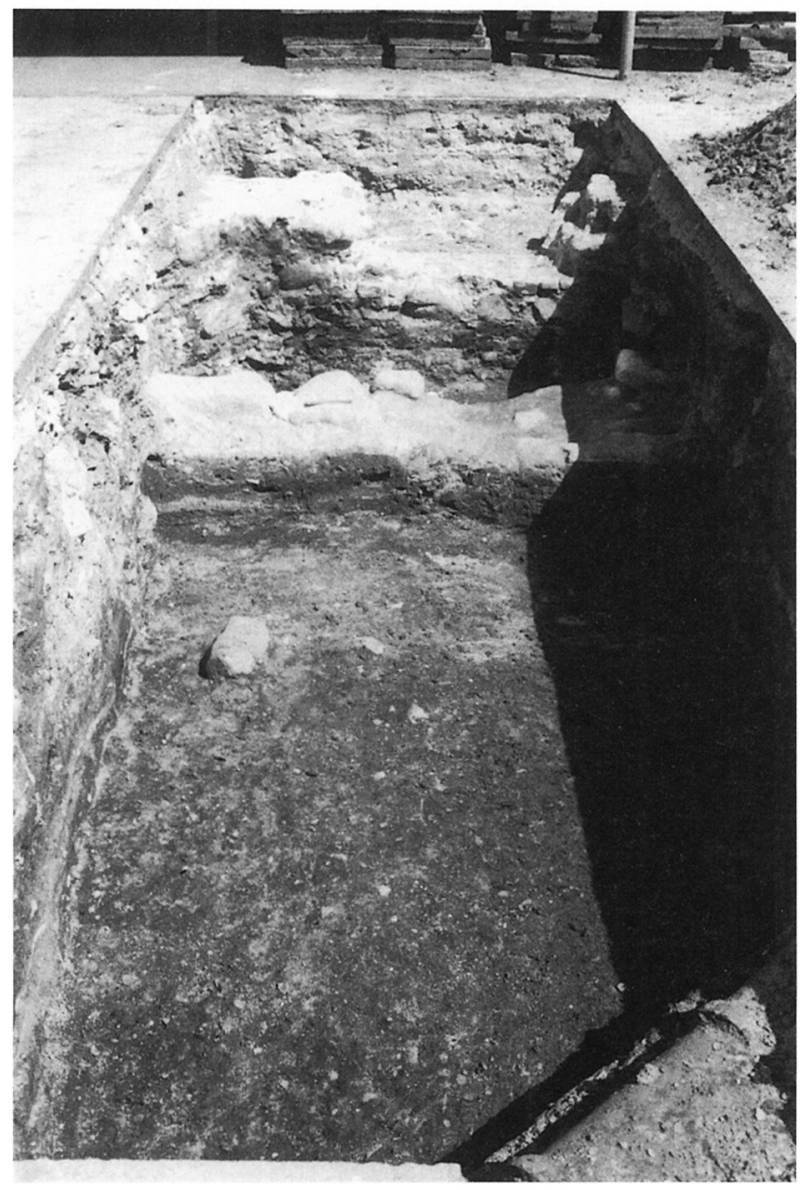

kendte godstype I (9). Fra disse lag kom også lidt kammageraffald af kronhjortetak, skår af klæberstensgryder samt lidt jernslagger.

Lagene fra ca. 1200-1250 indeholdt især den føromtalte Østersøkeramik, men nu optræder der også hårdtbrændt sortgods af godstype II samt enkelte skår fra glaserede højmiddelalderlige kander (godstype III). Blandt metalsagerne skal fremhæeves en armbrøstbolt, en jernkniv, et par beslag, en hestesko samt nogle hesteskosøm og et større antal søm og klinknagler. Disse lag indeholdt teglstumper, hvilket viser, at de er afsat efter teglens opdukken i Århus omkring år 1200.

Lagene fra 1500-1600-årene indeholdt især hårdtbrændt sortgods af godstype II samt glaserede efterreformatoriske skår af godstype III. En simpel kakkelpotte fra en kakkelovn var et af de mere interessante fund. Et enkelt blåligt stykke rudeglas hører også denne tid til. Forekomster af små gule såvel som røde teglsten vidner også om en datering til efterreformatorisk tid. 


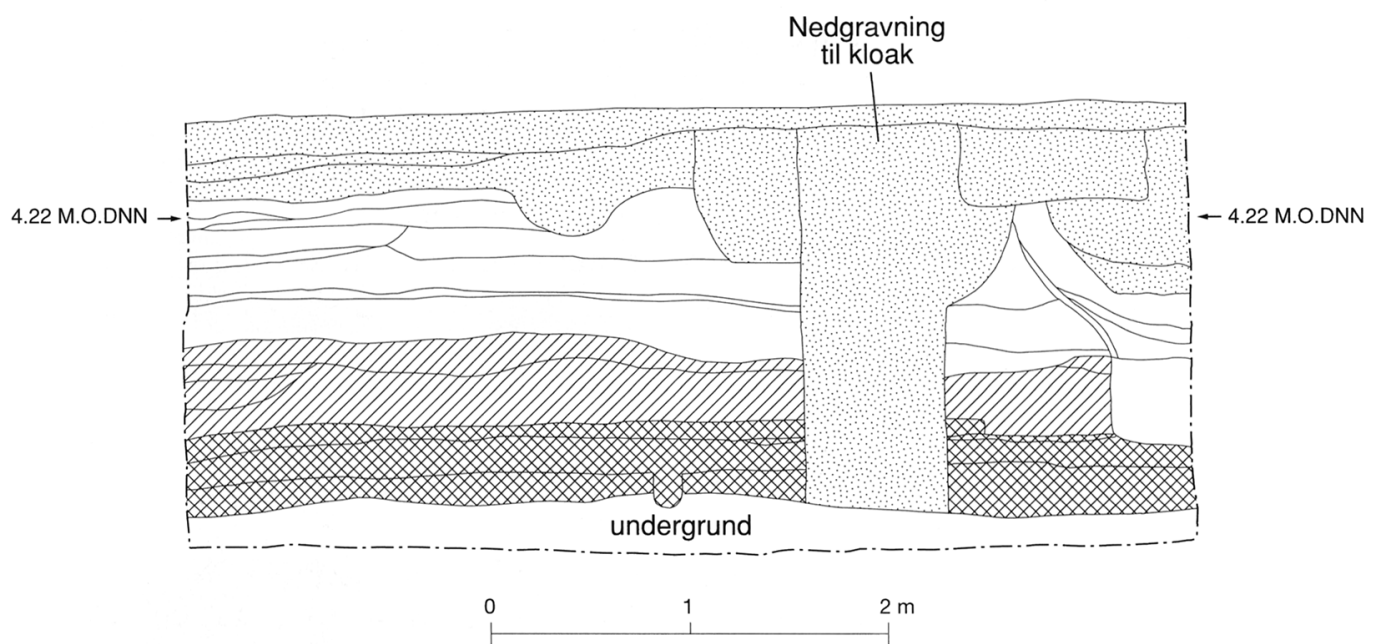

Fig.4. Vestprofilen i Felt I. De moderne lag er angivet med priksignatur. Lagene fra 15-1600årene er transparente. Middelalderlagene fra ca. 1200-1250 er vist med skråskravering. Vikingetidslagene er angivet med krydsskravering.

West section of square I. The recent deposits are stippled. The layers from the 16th 17th centuries are white. The Medieval layers from ca. 1200-1250 are obliquely hatched. The Viking layers are cross-hatched.

I det omrodede nedgravningsfyld til bygningen, der blev nedrevet $i$ 1950'erne, fandtes en dårligt bevaret borgerkrigsmønt, formentlig slået under Erik Menved først i 1300-årene. Anlægsarbejdet må have forstyrret kulturlag fra middelalderen.

Felt II var placeret på et sted med langt færre dybtgående forstyrrelser, end det var tilfældet i Felt I. Umiddelbart under det sand, som overfladefliserne var lagt $i$, dukkede uforstyrrede efterreformatoriske kulturlag op (fig. 5). Tykkelsen af disse lag varierede mellem $32-118 \mathrm{~cm}$. Herunder ses teglførende middelalderlag fra ca. 1200-1400. Toppen af disse lag ligger omkring kote 4,00 m. over DNN, og de er mellem 32-90 cm tykke. Under de teglførende middelalderlag ses teglfrie middelalderlag, der kan dateres til ca. 1050-1200. Topkoten af de teglfrie lag ligger omkring kote 3,40 m. over DNN. Lagene er mellem 20-64 cm tykke. Nederst ses lag afsat i tiden ca. 900-1000-årene. Topkoten på disse vikingetids lag er omkring kote $2,90 \mathrm{~m}$. over DNN. Tykkelsen på vikingetidslagene varierer mellem 45-85 cm i Felt II. Topkoten på undergrundssandet ligger omkring kote $2,11 \mathrm{~m}$. over DNN, hvilket betyder, at der under fliserne på dette sted er afsat op til 2,55 m kulturlag siden 900-årene. Det er værd at bemærke, at topkoten for undergrunden i Felt II ligger $90 \mathrm{~cm}$ lavere end i Felt I. Niveauforskellen, tyder på, at Felt II ligger på begyndelsen til kystskråningen ned mod stranden. 
I de efterreformatoriske lag fra 1500-1600-årene kunne man se hjørnet af hvad der tolkes som et hus, jf. bj på fig. 2(10). Husets fundament bestod af svære kampesten sat i gult ler. Gulvet i huset bestod af en brolægning af sten sat på højkant $i$ gult ler. Husets orientering kunne ikke bestemmes ud fra den smule, der blev afdrkket. Det er opført engang i 1500-1600-årene, mens tidspunktet for nedrivningen ikke med sikkerhed kan bestemmes ad arkæologisk vej. En brolægning, benævnt af, der synes jævngammel med huset, lå i bunden af de efterreformatoriske lag. (Jf. fig. 5).

I Felt II's modsatte sydøst-hjørne, langt nede i de middelalderlige kulturlag fra perioden ca. 1200-1400, sås murværket fra et teglbygget hus, benævnt $b f$. Murtykkelsen har været ca. $50 \mathrm{~cm}$. Muren er opført direkte på de underliggende kulturlag uden noget fundament. Gulvet $\mathrm{i}$ bygningen synes at have bestået af mørtel. Der er bevaret murværk i op til 4-5 skifter (fig. 6). Stratigrafisk kan huset dateres til at være opført tidligt i 1200-årene. Huset er jævngammelt med de første teglførende lag, som traditionelt dateres omkring 1200. Husets orientering passer med de

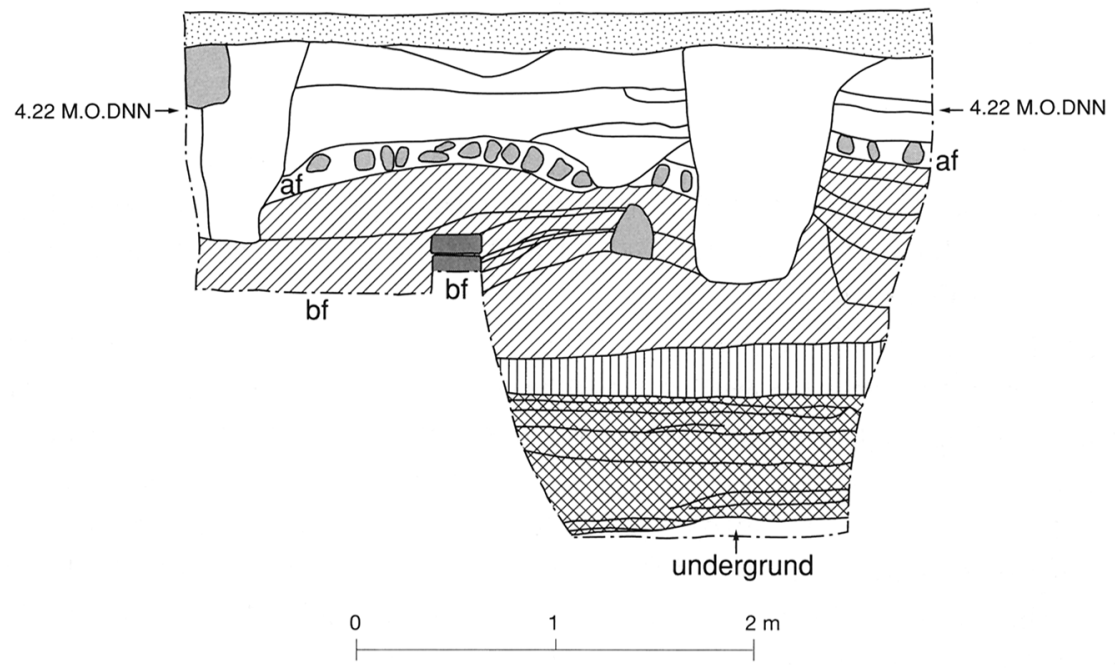

Fig. 5. Sydprofilen i Felt II. De moderne lag er angivet med priksignatur. De efterreformatoriske 1500-1600-tals lag er transparente. De teglførende middelalderlag fra ca. 1200-1400 er angivet med skråskravering. De teglfrie middelalderlag fra ca. 1050-1200 er angivet med lodret afstribning. Vikingetidslagene er vist med krydsskravering. Hus bf fra 1200 -årene er årsag til knækket i profilvæggen. Huset blev ikke bortgravet. Brolægning af fra 1500-1600-årene ses.

Southern section in Square II. The recent deposits are stippled. The post-Reformation layers from the 15-1600's are white. Medieval layers with brick fragments from ca. 1200-1400 are obliquely hatched. Medieval layers without brick fragments from ca. 1050-1200 are vertically hatched. The Viking layers are cross-hatched. The 13th century building bf is the cause of the bend in the section. It was not removed. Paving af from the 16th-17th centuries is visible. 


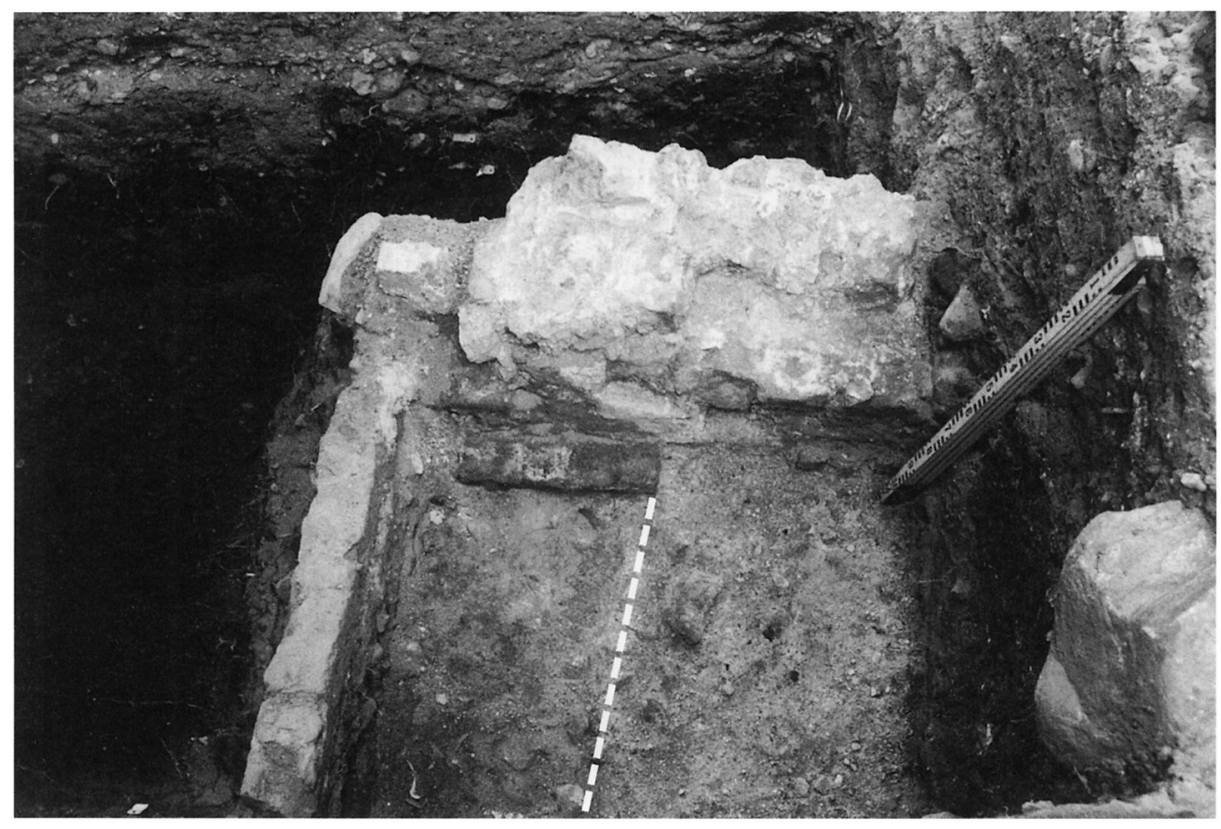

Fig. 6. Nordvesthjørnet af hus bf fra begyndelsen af 1200-årene. Bygningens vestgavl er næsten helt plyndret for mursten. Den stiplede linie angiver murens oprindelige bredde. Foto: H. Skov.

The NW corner of early 13th century building bf. Its western end had been almost completely robbed for bricks. The stippled line shows the original width of the wall. Photo H. Skov.

ruinrester, der blev påtruffet under Katerdralskolens "Den Røde Bygning" under dennes opførelse først i 1900-årene (11). Hvis de to ruindele stammer fra samme bygning, er der tale om et ca. $4 \times 8$ meter stort østvest orienteret hus. Et teglbygget hus fra årene omkring eller kort efter 1200 kan dårligt opfattes som en almindelig bygning. På den tid var tegl et eksklusivt byggemateriale, som var forbeholdt prestigebetonet byggeri, især af gejstlig karakter.

Da Katedralskolen var en integreret del af det gejstlige miljø omkring domkirken, forekommer det ikke usandsynligt, at huset kan være en del af det tidligste Katedralskolekompleks hørende til den nuværende domkirke, som iflg. de skriftlige kilder påbegyndes i løbet af 1190'erne (12). Under alle omstændigheder er hus bf et meget tidligt eksempel på en teglbygning, der ikke er en kirke. Bygningen synes nedrevet omkring 1400 .

I de teglfrie middelalderlag fra ca.1050-1100-årene påvistes rester fra tre forskellige lergulve og måske ildsteder, der har afløst hinanden. Lergulvene fortæller indirekte om tre huse eller bygningsfaser, der har ligget på samme sted og afløst hinanden. P.g.a. feltets lidenhed, kan der ikke siges noget om størrelsen på huset/husene. Lergulvene var placeret vest for teglbygningen $b f$. 
Endelig blev en mulig rest af et lergulv fra vikingetiden påtruffet vest for teglbygningen bf Der var flere stolpehuller og gruber i undergrundsniveau, men det var ikke muligt at se noget system i fyldskifterne.

Fundene i Felt II var mere varierede end i Felt I. Keramik er langt den mest almindelige fundgruppe. I lagene fra vikingetiden dominerer skår fra halvkuglekar, men slavisk influeret Østersøkeramik ses også. Der blev fundet to koniske ténvægte og en dobbeltkonisk ténvægt, to bennåle med gennemboring, mere end 100 stykker kammageraffald og hjortetak, en pilespids af jern samt søm, klinknagler og jernslagger. I de teglfrie middelalderlag var lokalt produceret Østersøkeramik næsten enerådende. Kun ganske fă skår af godstype II fandtes i disse lag. Et stykke Pingsdorf keramik fra Köln-området havde også fundet vej til disse lag. Et enkelt stykke klæberstensskår, en lille skiferslibesten med ophængningshul og et stykke kværnsten af granatglimmerskifer er eksempler på import fra Norge.

Dele af to vævevægte af ler, lidt kammageraffald af hjortetak og kobberslagger giver et fingerpeg om hvilke håndværk, der var at finde i området før Katedralskolens grundlæggelse på stedet. Fra de teglfrie middelalderlag stammer også en sølvmønt slået $\mathrm{i}$ Viborg under Svend Estridsen (1047-75) (fig. 7). Mønter fra denne tid er bestemt ikke hverdagskost.

De teglførende middelalderlag fra ca. 1200-1400, viser en gradvis overgang fra en jæun fordeling af keramik af godstype I og godstypeII til en klar dominans af godstype II i disse lags øverste dele. Godstype III er også godt
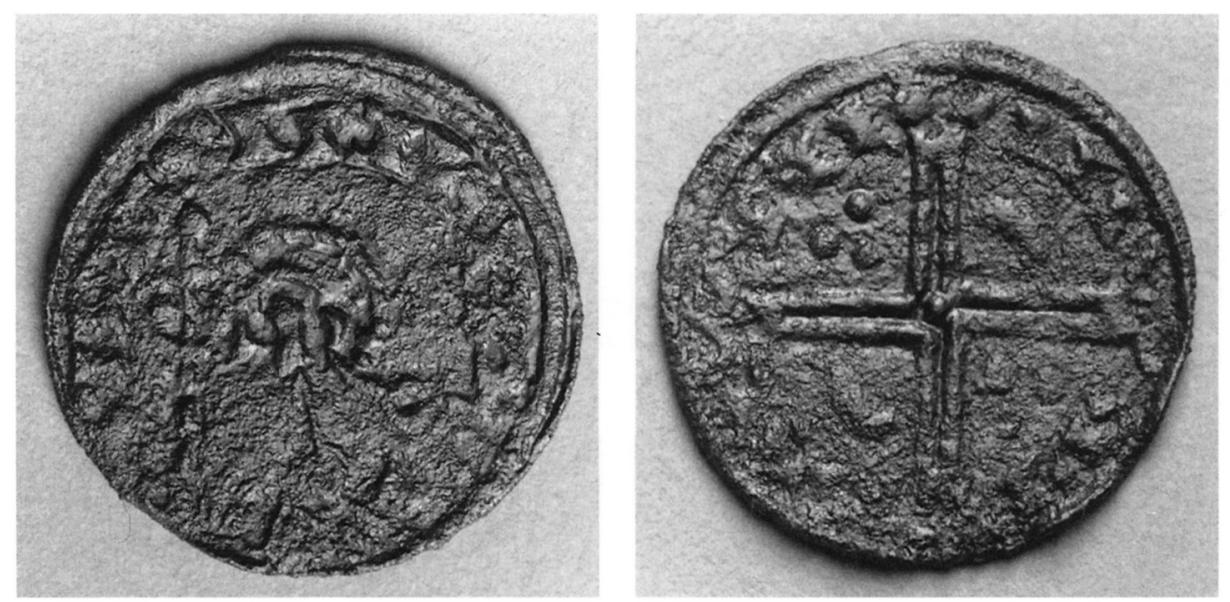

Fig. 7. Sølvmønt slået i Viborg under Svend Estridsen (1047-1075). På den ene side ses et korsmotiv omgivet af en uklar tekst. På den anden side ses en person med liljescepter omgivet af uklar tekst. Møntens diameter er 1,8 cm. Foto: P. Dehlholm.

Silver coin struck in Viborg under Svend Estridsen (1047-1075). On one side is a cross surrounded by an illegible text. On the other is seen a person with lily sceptre surrounded by an illegible text. The diameter of the coin is $1,8 \mathrm{~cm}$. Photo P. Dehlholm. 
repræsenteret i de øverste dele af de teglførende lag, mens de er fraværende i disse lags nederste dele. Import i form af næsten-stentøj fra Rhin-området viser, at varer fra dette område stadig fandt vej til Århus. Enkelte stykker rudeglas i de øverste lag peger frem mod senmiddelalderen.

Det mest opsigtsvækkende enkeltfund fra udgravningen var en kun $7,8 \mathrm{~cm}$ lang asymmetrisk dobbeltkam af elsdyrtak eller rentak (fig.8). Det usædvanlige ved dobbeltkammen er, at de to kamsider sidder forskudt i forhold til hinanden, hvor det normale er, at de to kamsæt sidder symmetrisk ryg mod ryg. At kammens design er fuldt tilsigtet ses dels af stykkets elegante linjer og dels ved nærmere studium af de forskellige dele, kammen er sammensat af (fig. 9). Kammen består af syv dele, nemlig fem tandsektioner, hvoraf den midterste betinger S-formen, og to skinner, der med hjælp af fire kobbernitter fastholder hele herligheden. Stykkerne kan kun samles på én måde, og den virker særdeles gennemtænkt. Kammens dimensioner og hele udformning gør den fortrinligt egnet til skægpleje. Forfatteren har selv erfaret, at den asymmetriske form er en fordel, når man under skægfriseringen ønsker at skifte fra siden med de grove til siden med de fine kamtænder og vice versa. Man opdager hurtigt, at en fiks bevægelse med fingrene kan dreje kammen 180 grader, hvorved den nye kamside træder til med samme effektivitet som den gamle. Den lille opfindelse med de to forskudte tandsæt har gjort kammen ekstra brugervenlig (13).

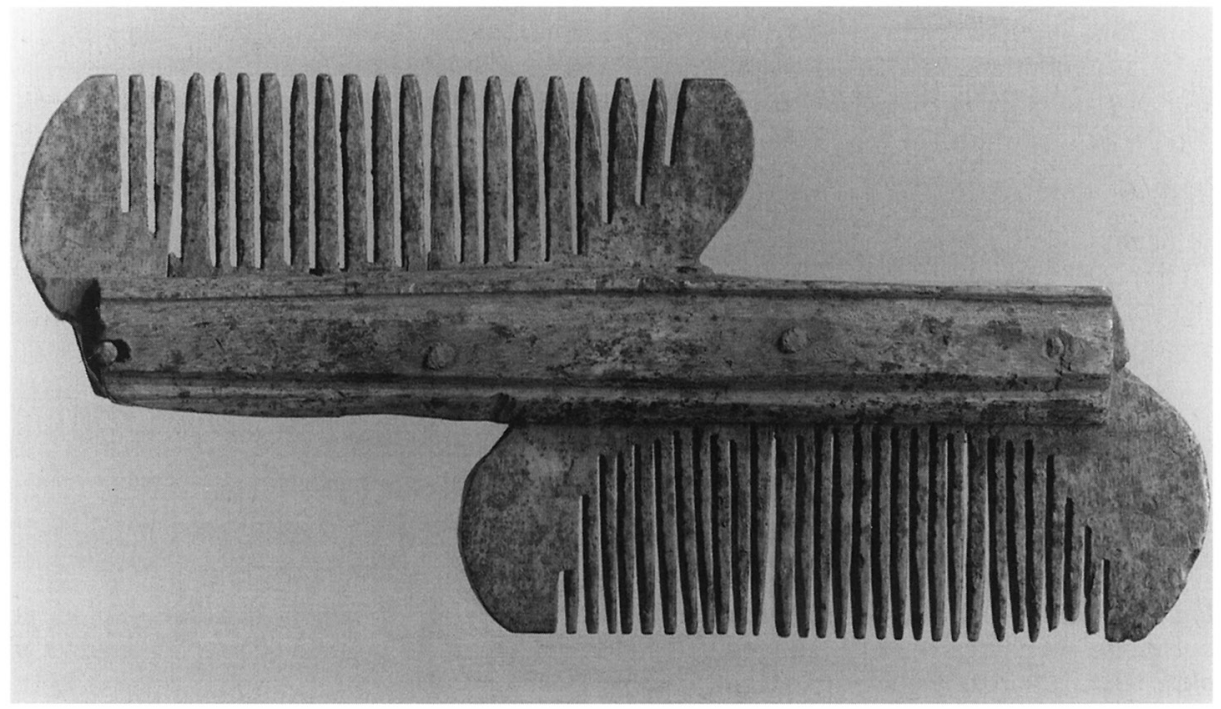

Fig. 8. Asymmetrisk dobbeltkam lavet i tak. Kammen måler kun $7,8 \mathrm{~cm}$ i længden. Foto: P. Dehlholm.

Asymetrical double comb of antler, length $7.8 \mathrm{~cm}$. Photo P. Dehlholm. 
Fig. 9. De syv dele, som Århuskammen er sammensat af. Efter Skalk 1995.

The seven pieces which combine to make the Århus comb. After Skalk 1995.

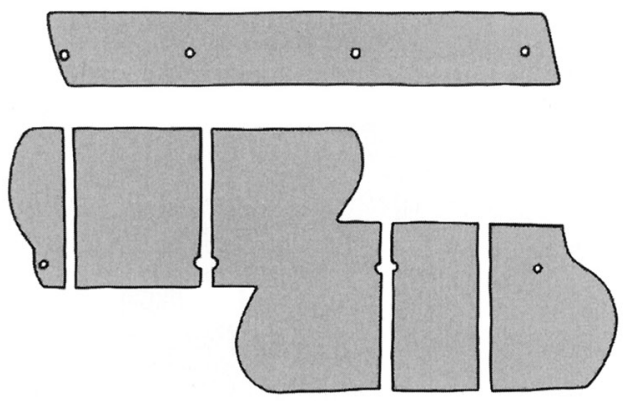

Kammen blev fundet i lag, der stratigrafisk kan dateres til midten af 1200-tallet. En eftersøgning efter tilsvarende asymmetriske dobbeltkamme viste, at typen er overordentlig sjælden. Med Århus-kammen kendes $i$ alt kun 12 af denne særegne kamtype. Heraf stammer en fra Slesvig, tre fra Caithness i Nordskotland og syv fra Norge fordelt på tre fra Tønsberg, en fra Skien, en fra Bergen og to fra Trondheim (14). Blandt de spørgsmål, som naturligt melder sig, er, hvor denne kamform har sit hjemsted. Fundspredningen tyder på en eller flere af de norske kystbyer som produktionssted. De tre kamme fra det nordlige Skotland er netop fundet i et område, der var beboet af udvandrede nordmænd, der frem til 1200-tallet opretholdt tætte forbindelser til det gamle fædreland. Det faktum, at Århus-kammen ikke er fremstillet i det hjemlige kronhjortetak, men i elsdyr- eller rentak, er et andet indicium på kammens norske herkomst. Den eksklusive asymmetriske kam har sandsynligvis fulgt sin norske ejer på en rejse til Århus og er ved et uheld tabt på Katedralskolens grund.

Fundene fra Felt II's efterreformatoriske 1500-1600-tals lag består især af keramik af godstype II i en udførelse, der giver mindelser om jydepottekeramik. Glaserede stjertpotter i godstype III er nu også ganske almindelige. De efterreformatoriske lag har forstyrret de ældre kulturlag fra 1300-1400-årene. En del fund fra denne tid findes opblandet med fund fra 1500-1600-årene.

\section{Udgravningen i Skolegyde}

I Skolegyde og Skolegade, der afgrænser Katedralskolekomplekset mod henholdsvis syd og vest, medførte udskiftning af fjernvarmeledninger i 1995, at der anlagdes grøfter på op til 1,8 meters bredde og 1,7 meters dybde (fig. 10). Fjernvarmegrøften begyndte i krydset mellem Skolegyde og Skolebakken og fortsatte langs Skolegydes nordside ud i Skolegade, hvor den fortsatte langs gadens vestside hen til Kvindemuseets bygning 


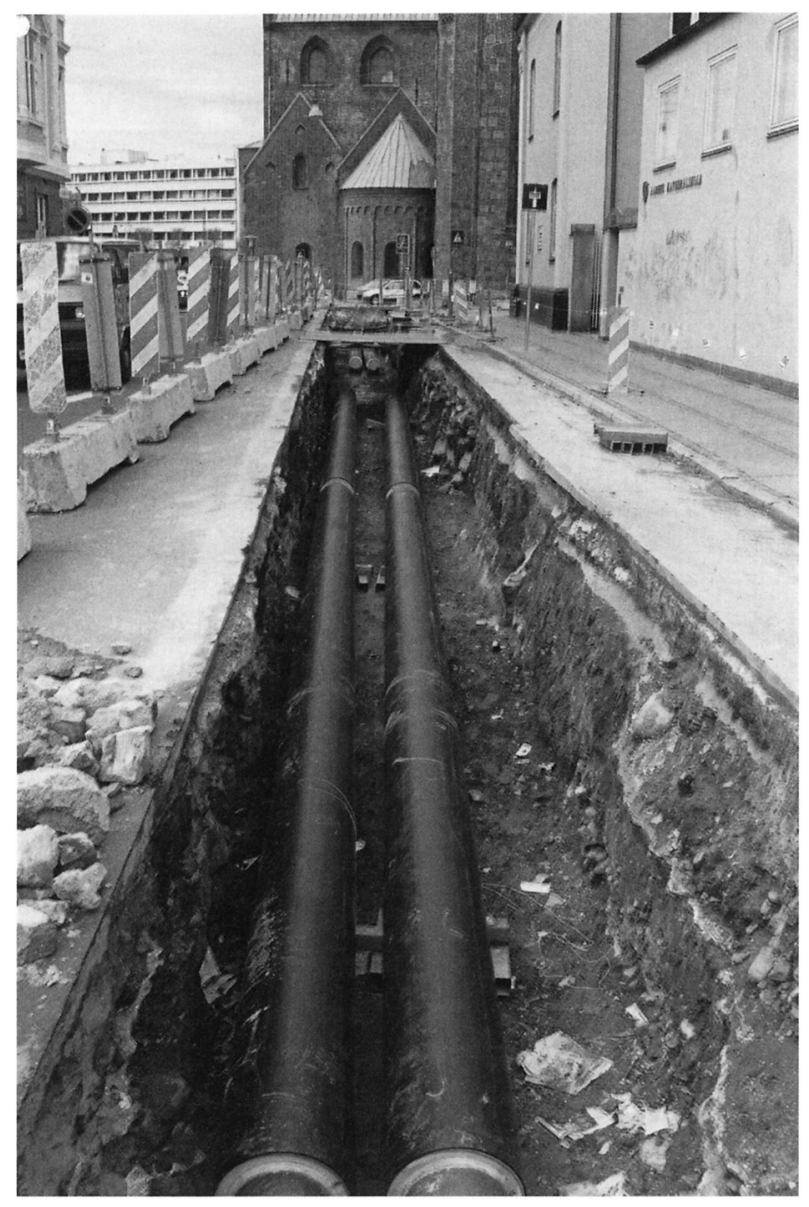

Fig. 10. Fjernvarmegrøften i Skolegyde set fra øst hen imod domkirken. Til højre ses Katedralskolen. Foto: H. Skov.

The distant heating trench in Skolegyde looking west towards the cathedral. Photo H. Skov.

på hjørnet af Mejlgade og Domkirkepladsen (fig.2). I fjernvarmegrøftens profilvægge i Skolegyde kunne man følge anlægsspor fra sen vikingetid i form af en nordvest-sydøst orienteret skelgrøft, flere gruber, tre middelalderhustomter samt endnu to hustomter fra nyere tid. Hustomterne gav sig til kende enten $i$ form af lergulve eller som stenfundamenter. Ler og fundamentsten viste, at en bygning benævnt ah havde stået i Skolegydes østlige ende. Ud fra keramikken at dømme, var huset i brug i 13001500-årene. P.g.a. forstyrrelser i lagene kan der ikke siges noget sikkert om husets dimensioner og orientering. Længere mod vest ud for Katedralskolens pedelbygning påvistes et kraftigt kampestensfundament over en strækning på 8 meter (fig. 11). Fundamentet, der benævnes hus av, kan knyttes til fundamentrester, der endnu ses i gulvet i pedelbygningen mod nord. Keramikken i hus av's fundament tyder på, at denne bygning også er opført i 1300-årene. Parallelt med hus av, men længere mod syd i Skolegyde, sås et lergulv over et forløb på $8,2 \mathrm{~m}$. Denne bygning, der er 
benævnt hus bg, dateres til 1300-1500-årene, og det er fristende at se hus bg som en lettere tilbygning til den mere bastante bygning av. Hus bg må have været en forholdsvis smal bygning eller tilbygning, der flugtede med Skolegyde. Det kan ikke udelukkes, at huslevnene ah, av og bg kan være dele af samme bygning. Det svære stenfundament til hus av kan eventuelt angive kælderdelen $i$ en lang øst-vest orienteret bygning. På Resens gengivelse af området ved Katedralskolen fra ca. 1675 ses bl.a. et par store og lange bygninger, der vender gavlene ud mod Skolegade (fig. 12) (15). Den sydligste bygning på gengivelsen fra ca. 1675 kan enten være en efterfølger af ovennævnte husdele, eller eventuelt i et vist omfang være identisk med disse. De arkæologiske udsagn tyder dog på, at den førstnævnte tolkning er den mest sandsynlige.

Til belysning af Katedralskolens tidligere udformning er Resens og andre samtidige Århus-prospekter desværre af en sådan karakter, at det ikke er tilrådeligt at drage alt for vidtrækkende konklusioner på grundlag af disse, men de skriftlige kilder lader ane, at skolen ved reformationen og helt tilbage til 1415 bestod af mindst to bygninger som vist på bl.a. Resens tegning (16). Mens Resen i 1675 har to adskilte bygninger med gavle vendt ud mod Skolegade, viser et gammelt oliemaleri fra perioden 1634-42, at skolens storste bygning lå parallelt med Skolegade, mens en

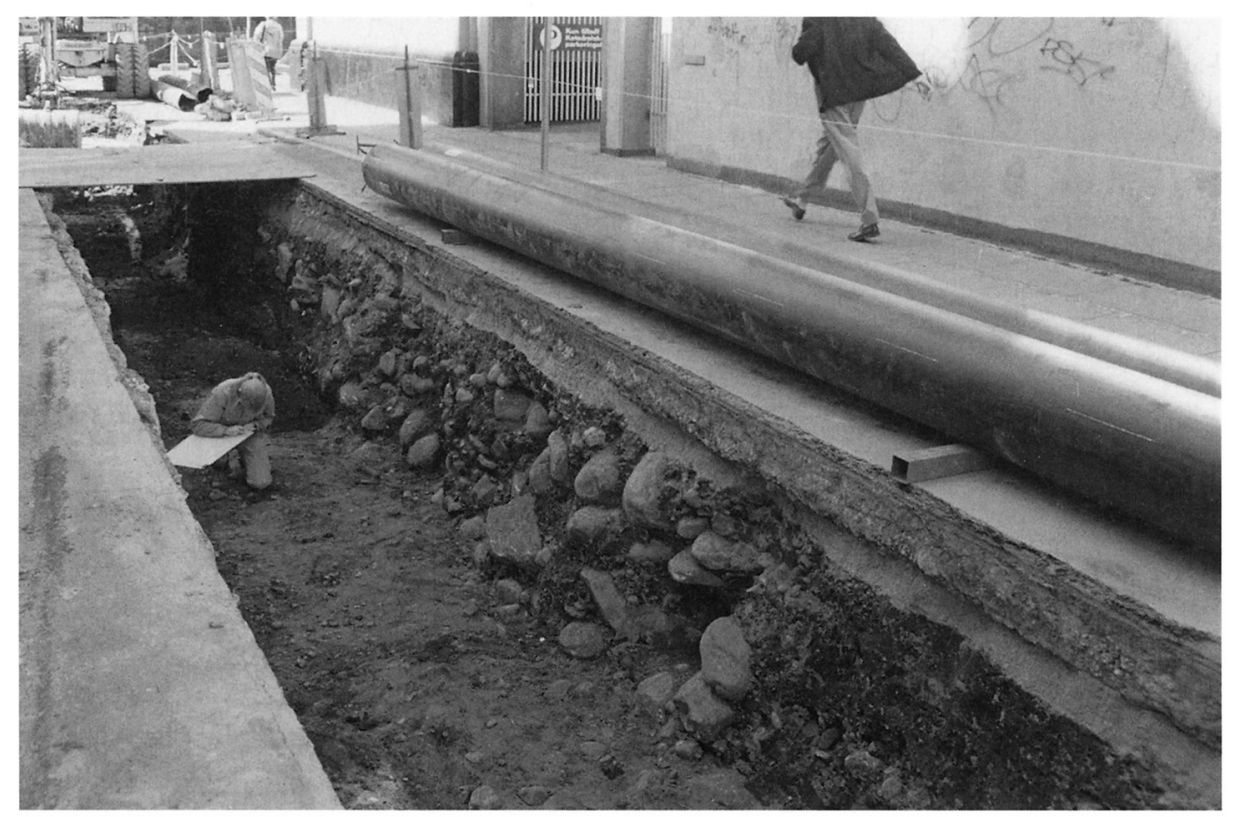

Fig. 11. I fjernvarmegrøften ses hus av's forstyrrede kampestenskælder. I baggrunden ses indgangsporten til Katedralskolen. Foto: H. Skov.

Disturbed stone cellar of building av. In the background the entrance gate to the Cathedral School. Photo H. Skov. 


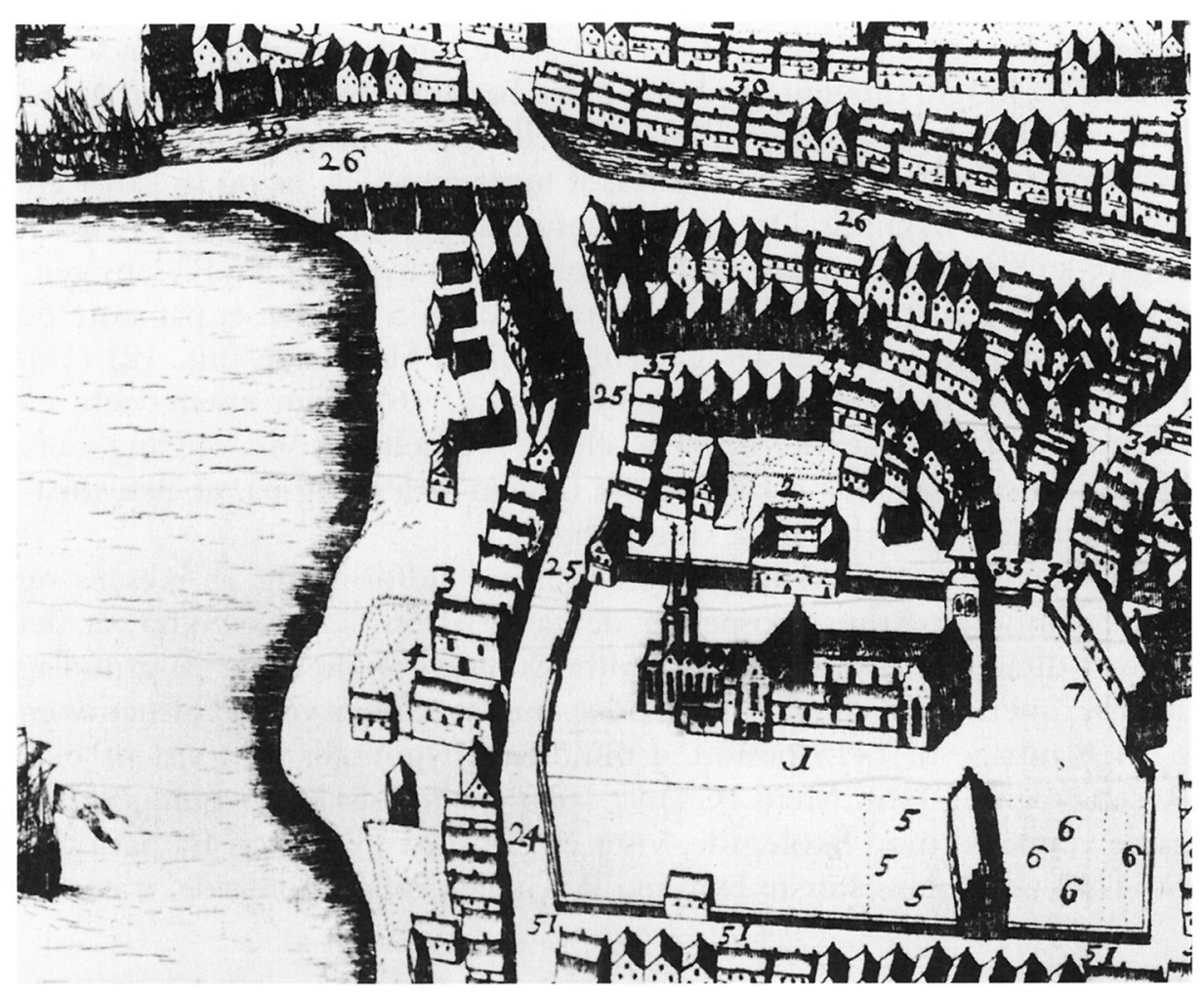

Fig. 12. Udsnit af Resens Århus prospekt fra ca. 1675. Byen er set fra nord. Katedralskolen er de to-tre bygninger ved tallene 3 og 4 . De to hovedfløje vender gavlene ud mod Skolegade. Selv skolegården synes indtegnet på dette kort. Kobberstik fra Peder Hansen Resens Atlas Danicus.

Part of Resen's prospect of Århus (ca. 1675). The town is seen from the north. The Cathedral School is the two or three buildings by the numbers 3 and 4 . The two main wings have gables facing Skolegade. Even the playground seems to be shown on this map. After Peder Hansen Resen's Atlas Danicus.

anden bygning lå langs Skolegyde (fig. 13) (17). Sidstnæunte bygning kan være identisk med Resens sydligste skolebygning (18). Skolens i øvrigt vidt forskellige udformning på de to prospekter skyldes formentlig fejlagtig gengivelse hos en af kunstnerne, og i denne sammenhæng kan man med god grund mistænke Resen for upræcise detaljer.

Helt frem til 1906 var Skolegyde en kun 3,8 m bred passage, på hvis nordside Katedralskolen bredte sig. I 1906 nedrev man en del af Katedralskolen, bl.a. en del af fløjen fra 1763, som et led i gadens udvidelse til den nuværende bredde. De i fjernvarmegrøften påviste bygningslevn fra nyere tid stammer netop fra den del af Katedralskolen, der måtte vige i 1906.

Terrænforholdene i Skolegyde svarede nøje til de påviste forhold i skolegården. Terrænet falder jæunt fra Skolegade i vest ned mod gaden Skolebakken i øst. 


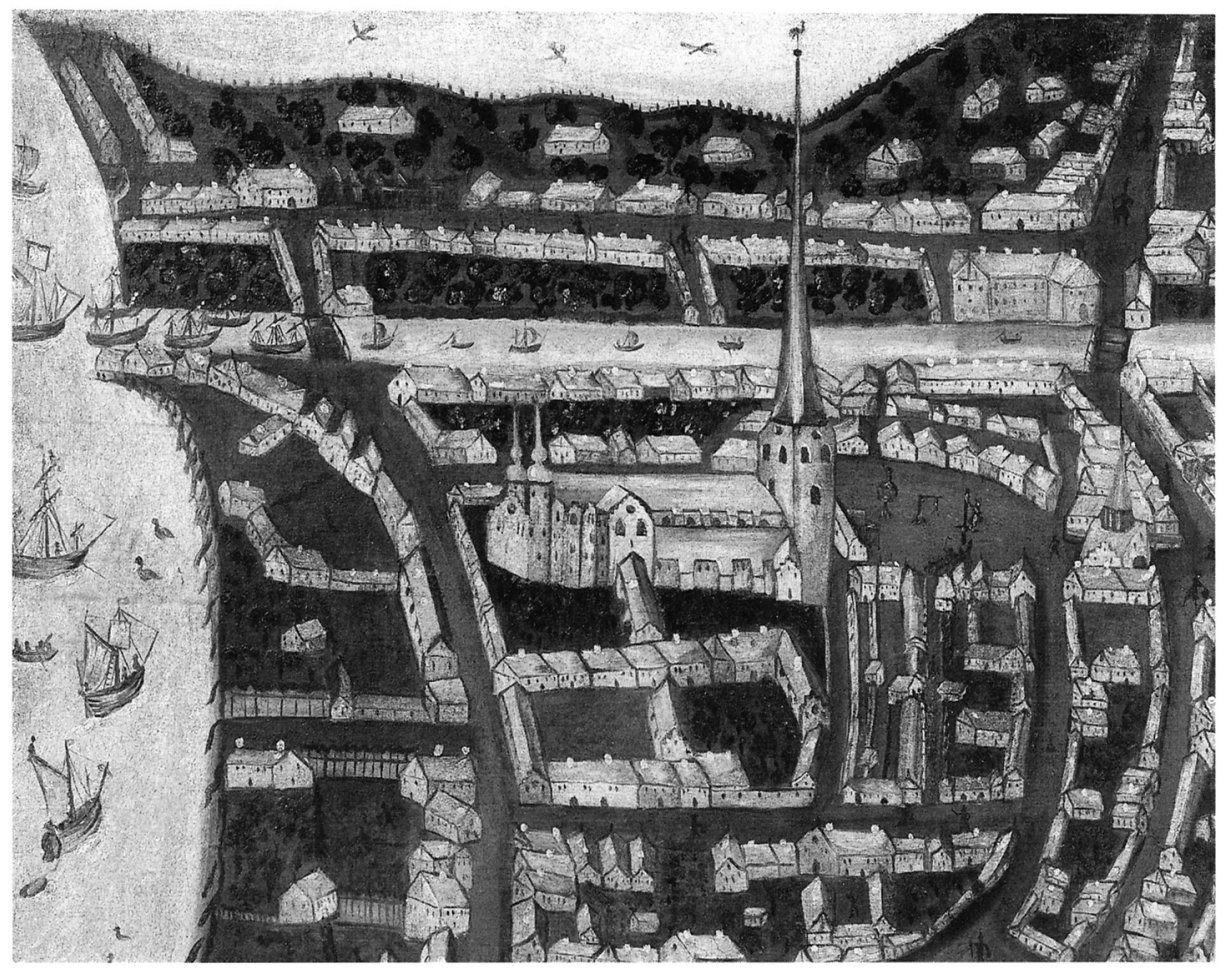

Fig. 13. Udsnit af oliemaleri af Århus fra 1634-42. Byen er set fra nord. Katedralskolen synes her gengivet som et vinkelkompleks med en hovedfløj langs Skolegade og en mindre fløj langs Skolegyde. Fløjen langs Skolegyde er sikkert identisk med Resens hus nr. 3. Oliemaleri i Den gamle By. Foto: P. Pedersen.

Part of an oil painting of Århus dated 1634-42. The town is seen from the north. The Cathedral School appears to be shown as a L-shaped complex with a main wing along Skolegade and a smaller wing along Skolegyde. The wing along Skolegyde is certainly the same as Resen's house 3. Oil painting in the museum, Den Gamle By. Photo: P. Pedersen.

Fundene i Skolegyde udgøres primært af keramik af godstyperne I, II og III, med godstype II som den mest almindelig form i kulturlag fra ca.1200 og senere. Hjemligt produceret Østersøkeramik dominerer derimod i kulturlagene fra før 1200. Ganske lidt kammageraffald af tak fremkom i skelgrøften fra sen vikingetid. Fundmængden var i forhold til udgravningen i skolegården beskeden. Dette skyldes, at fjernvarmegrøfterne ved etableringen for mange år siden allerede dengang blev tømt for kulturlag og oldsager, og at der ved den her omtalte arkæologiske undersøgelse kun var lejlighed til at lede efter fund i profilerne.

\section{Konklusion}

De arkæologiske udgravninger i Katedralskolens skolegård $\left(32 \mathrm{~m}^{2}\right)$ og i Skolegyde $\left(72 \mathrm{~m}^{2}\right)$ har påvist en række lagserier og bygningslevn fra 
vikingetid frem til nyere tid. Kulturlagenes samlede tykkelse varierer mellem 1,8-2,5 m. Lagserierne er ingen steder ubrudte i dette lange tidsrum. Der forekommer tidsmæssige spring på flere hundrede år, der vidner om forsegling eller afgravninger på Katerdralskolens gamle grund. Spredte stolpehuller og enkelte lergulve er de eneste bebyggelsespor fra vikingetiden og tidlig middelalder. Der blev ikke påvist grubehuse $\mathrm{i}$ modsætning til den tidligere udgravning længst mod nord $\mathrm{i}$ den nuværende skolegård. Helt i tråd med undersøgelsen fra 1969 blev der ikke påvist spor af befæstning langs kystskrænten. Fra skolens ældste tid først i 1200-årene er en mindre teglbygget bygning bf påvist ganske nær kystskrænten. Skolens øvrige bygninger fra denne tid er ikke blevet påvist ved de arealmæssigt beskedne udgravninger. Hus bf nedrives omkring 1400. Fra 1300-årene og formentlig helt frem til skolens fornyelse i 1763 er arealet langs Skolegyde bebygget af en eller flere bygninger. En del af det bebyggede areal langs Skolegyde synes at have været forsynet med en stensat kælder. Det arkæologiske fundmateriale viser, at bebyggelsen fra 1300-årene i det mindste bestod indtil ind i 1500-årene. Den senere nedrivning af de gamle skolebygninger var så grundige, at det er umuligt at afgøre, om bygningsmassen fra 1300-årene overlevede helt til 1763 eller blev udskiftet engang i 1500-årene. I 1500-1600-årene opføres hus bj få meter nord for skolefløjen langs Skolegyde. P.g.a. udgravningens begrænsede omfang kan der ikke siges noget sikkert om hus bj's orientering og størrelse. Hus bj forsvandt formentlig i forbindelse med skolens fornyelse i 1763. Længere mod nord på skolens grund blev fundamentet til den gamle rektorbolig fra 1700-årene påtruffet. Den gamle nedrevne rektorbolig markerede nordgrænsen for den oprindelige Katedralskolematrikel, og det er først i nyere tid, at matriklen med den nordligste del af skolegården m.m. er blevet en del af skolen.

De arkæologiske undersøgelser har nu stedfæstet og dateret en mindre del af den gamle skoles bygningsmasse, men et helhedsbillede af Katedralskolekomplekset vil vi formentlig først fă ved langt mere omfattende udgravninger i skolegården. Kulturlagenes bevaringstilstand og områdets interessante historie vil uden tvivl anspore til, at der ved lejlighed igen bliver foretaget arkæologiske undersøgelser i dette område. 


\section{Noter}

1) Udgifterne til udgravningen FHM. j.nr. 3833 Aarhus Katedralskole blev venligst betalt af Århus Kommune. Udgravningen blev foretaget af stud.mag'erne Lene Birgitte Højrup, Anne Birgitte Jessen, Thomas Aagaard Kristensen, Lars Krants Larsen og Ida Lauridsen, samt gymnasieelev ved Katedralskolen Jens Martin Højrup. Cand.mag Hans Skov var udgravningsleder.

2) Udgifterne til de arkæologiske undersøgelser i Skolegade og Skolegyde (FHM. j.nr. 3945) blev i henhold til Museumsloven betalt af Århus Kommunes Fjernvarmeforsyning. De arkæologiske undersøgelser blev foretaget af cand.mag Jette Linaa Larsen og cand.mag Hans Skov, der var udgravningsleder.

3) H.Paludan, 1996, p. 150-151.

4) H.Paludan, 1996, p. 151-152.

5) H.H. Andersen \& H.J. Madsen, 1985, p. 35-95.

6) Jf. tegninger i "Efterretninger om Aarhus Kathedralskole i Skoleaaret 1906-1907") Aarhus Kathedralskole 1907, p. 10-11.

7) En tegning af Chr. Blache fra 1861 viser denne bygning. Tegningen opbevares på Aarhus Katedralskole.

8) H.H. Andersen \& H.J. Madsen, 1985, p. 36-38.

9) Se H.H. Andersen, P.J. Crabb \& H.J. Madsen, 1971, p. 64-105, og p. 262-264.

10) Da kun en smule af "hus" bj er udgravet kan det ikke udelukkes, at der er tale om en mystisk stensat grube i stil med den der blev påvist ved Århus Søndervold. Se H.H. Andersen, P.J. Crabb \& H.J. Madsen 1971 fig. 47-50 p. 63.

11) Ruindelene, der er tale om, ses øst for pedellens gård på kortet s. 10 i "Efterretninger om Aarhus Kathedralskole i Skoleåret 1906-1907. Aarhus 1907.

12) Danmarks Kirker, Århus Amt, bd. 3. p. 1003-1004.

13) H. Skov, 1995. p. 20-21.

14) C.E. Batey, 1987, p. 209-210, 227 og 479. L. Flodin, 1989, fig. 44 og ill. 35. S. Myrvoll, 1983, p. 273, og Taf. 9,4. I. Ulbricht, 1984, p. 53, og Taf. 32. Bergen kammen er upubliceret. Den opbevares på Bryggens Museum under nr. 61211. Tønsberg kammene er upubliceret. De opbevares hos IAKN Oldsaksamlingen i Oslo under journalnr. C 35127- TR 4944, TR 5944, TR 6225.

15) O. Degn, 1996, p. 248.

16) R. Knudsen, 1941, p. 168.

17) O. Degn, 1996, p. 245.

18) R. Knudsen, 1941, p. 178.

\section{LITTERATUR}

Andersen, H.H., P.J. Crabb \& H.J. Madsen 1971: Arhus Sondervold. Jysk Arkæologisk Selskabs Skrifter IX. Århus.

Andersen, H.H. \& H.J. Madsen 1985: Byudgravning ved Århus Katedralskole. Kuml 1985.

Batey, C.E. 1987: Freswick Links, Caithness. A re-appraisal of the Late Norse site in its context. $B A R$ British Series 179 (ii). Oxford.

Danmarks Kirker. Arhus Amt. København u.å.

Degn, O. 1996: Borgernes By 1550-1720. Ib Gejl (red.): Arhus - Byens Historie, bd. 1. Århus.

Efterretninger om Aarhus Kathedralskole. 1907. Aarhus.

Flodin, L.1989: Kammakeriet i Trondheim ca. 1000-1600. Meddelelser Nr. 14 (Fortiden i Trondheim Bygrunn: Folkebibliotekstomten). Trondheim.

Knudsen, R. 1941: Århus gennem Tiderne, bd. III. Århus.

Myrvoll, S. 1983: The town of Skien, Norway. - Lübecker Schriften zur Archäeologie und Kulturgeschichte, Bd. 7. Bonn.

Paludan, H. 1996: Bispestaden 1100-1550. Ib. Gejl (red.): Århus - Byens Historie, bd. 1. Århus.

Skov, H. 1995: Legemspleje. Skalk 4, 1995.

Ulbricht, I. 1984: Die Verarbeitung von Knochen, Geweih und Horn im mittelalterlichen Schleswig. Ausgrabungen in Schleswig, Bd. 3. Neumünster. 


\section{Excavations at Aarhus Cathedral School in 1994-95}

In 1994-95 archaeological excavations were conducted on the property of Aarhus Cathedral School in central Århus (fig.1). Two areas in the playground with a combined size of $32 \mathrm{~m}^{2}$, and a $72 \mathrm{~m}^{2}$ distant heating trench in the street called Skolegyde were excavated (fig. 2, 3, 6 and 10). The stratigraphy extended from Viking until recent times, but nowhere was there an unbroken sequence of layers covering the whole period (fig.4, fig.5). There are gaps of several hundred years, which are evidence of sealing or digging on the old cadaster. Scattered postholes and a few clay floors are all the traces that survive from Viking and early Medieval times. No sunken huts were found, in contrast to the earlier excavation in the most northerly part of the present playground. Just as in 1969 no trace of defensive works were found along the slope to the shore.

From the first period of the school in the early 13 th century came a small brick building (bf, fig.6.). Its walls rested directly on the occupation layer without any foundations. It had been ca. $8 \mathrm{~m}$ long and $4 \mathrm{~m}$ wide and had a mortar floor. House bf was demolished in about 1400 .

Excavation along the heating trench showed that here had been continuity of settlement from the 14 th century probably until the school was extensively rebuilt in 1763. One or more buildings here belonged to the school. Part of the complex, whose gable faced the road, Skolegade, seems to have had a stone cellar (fig.11). Fig. 12 and 13 show the earliest pictures of the buildings of the Cathedral School in the 1600 )'s. Probably the building along Skolegyde is the same or nearly the same as the remains found along the pipeline. A little north of house bf house bj was erected in the 15-160)'s. It rested on a foundation of large granite blocks, and the floor was cobbled with small stones set in clay (fig.2).

The finds were mostly pottery, iron, and waste from comb production. Attention is called to a crossbow bolt, an arrowhead, an iron knife, a horseshoe, some nails and rivets, a biconical and two conical spindle whorls, two bone pins, and a copper coin of the 14 th century. One of the more unusual finds was a silver coin from the reign of Svend Estridsen in the 11 th century (fig.7). More unique was an asymetrical double comb, that seems to have been well adapted to looking after the beard (fig.8, fig.9). The comb is of elk or reindeer antler, materials that did not occur naturally in Medieval Jutland, but did in Norway, where seven combs of the same type have been found. Three more are known from the Norse part of Caithness in Scotland, and one from Schleswig.

Hans Skov

Moesgård Museum 